\title{
Spatial variability and long-term analysis of groundwater quality of Faisalabad industrial zone
}

\author{
Muhammad Salman Nasir ${ }^{1}$ (D) Abdul Nasir $^{1} \cdot$ Haroon Rashid $^{1} \cdot$ \\ Syed Hamid Hussain Shah ${ }^{2}$
}

Received: 21 April 2016/Accepted: 31 August 2016/Published online: 13 September 2016

(C) The Author(s) 2016. This article is published with open access at Springerlink.com

\begin{abstract}
Water is the basic necessity of life and is essential for healthy society. In this study, groundwater quality analysis was carried out for the industrial zone of Faisalabad city. Sixty samples of groundwater were collected from the study area. The quality maps of deliberately analyzed results were prepared in GIS. The collected samples were analyzed for chemical parameters and heavy metals, such as total hardness, alkalinity, cadmium, arsenic, nickel, lead, and fluoride, and then, the results were compared with the WHO guidelines. The values of these results were represented by a mapping of quality parameters using the ArcView GIS v9.3, and IDW was used for raster interpolation. The long-term analysis of these parameters has been carried out using the 'R Statistical' software. It was concluded that water is partially not fit for drinking, and direct use of this groundwater may cause health issues.
\end{abstract}

Keywords Groundwater · Parameters · GIS · IDW · Contamination $\cdot$ Interpolation

\section{Introduction}

Water is the basic necessity of life (Uberoi 2010) and it plays an important role in the earth's ecology. It is one of the most serious, rare, and valuable natural resource that cannot be created (Kouras et al. 2007). Groundwater is the

Muhammad Salman Nasir

salmannasir@uaf.edu.pk

1 Department of Structures and Environmental Engineering, University of Agriculture Faisalabad, Faisalabad, Pakistan

2 Department of Irrigation and Drainage, University of Agriculture Faisalabad, Faisalabad, Pakistan main source in the urban environment, which is used for drinking, industrial, and domestic purposes. Over exploitation of groundwater causes serious threats to its quantity. The groundwater is degraded due to increase in population, rapid industrialization, and improper waste management practices in urban areas.

In Pakistan, groundwater contamination is mainly due to the byproducts of different industries, such as sugar processing, textile, dying, cement, leather, fertilizers, pesticides, food processing, and others. These industrial effluents have leached down from the drain and pollute the groundwater (Rizwan and Riffat 2009).

Water quality of main cities of Pakistan, such as Sialkot, Gujarat, Faisalabad, Karachi, Qasur, Peshawar, Lahore, Rawalpindi, and Sheikhupura, has deteriorated due to the uncontrolled disposal of urban wastewater and untreated industrial wastewater and excessive use of fertilizers and insecticides (Bhutta et al. 2002). These industrial effluents have leached down from the drain and pollute the groundwater. Groundwater is the major source of drinking and industrial water use.

Faisalabad city has made rapid progress in the industry since independence. It is famous for its different industries, such as paper, leather, textile, sugar, vegetable oil, soaps, detergents, and many other industries. As a result of industries, a large amount of organic and inorganic solid wastes and heavy metals are being disposed of into the natural streams and drains (Farah et al. 2002). The groundwater is badly affected due to the haphazard construction of different industries which discharge their untreated polluted effluent into open fields around them (Qadir et al. 2008).

In several places of Faisalabad, the level of groundwater is lowered due to the increased pressure on groundwater (Nasir et al. 2016). The water table has dropped more than 
$10 \mathrm{~m}$ in several areas (Asma et al. 2012). Therefore, the quality of groundwater is also influenced by the continuous use of groundwater (Kahlown and Muhammad 2003). The analysis of heavy metals is necessary to check the condition of water quality to determine its suitability for its further use (Round 1997).

This study was conducted to estimate the water quality in the industrial zone and to prepare a quality map using geographic information system (GIS). It offers great opportunities for the simulation of groundwater mapping (Dixon 2005). GIS is a powerful tool for understanding the present and future scenario of groundwater quality and provides a data for contaminated zone (Al Hallaq and Elaish 2012).

\section{Materials and methods}

\section{Study area}

The area of the industrial zone of Faisalabad city shown in Fig. 1 was selected for this study with the criteria that industrial drains pass through the area which is expected to be the main source of contamination.

\section{Sampling plan}

As part of the study, groundwater samples were collected from different areas. Samples were randomly taken from whole area of newly installed pumps to investigate the different water quality parameters in the groundwater. The samples were taken in $500 \mathrm{ml}$ bottles. The 60 water samples were collected in total from the groundwater. After the collection of the samples, the samples were preserved and analyzed in the laboratory.

\section{Location of sample points}

The location of sample points was found with the help of co-ordinates of points. The co-ordinates of the sample points were taken with the help of Global Positioning System receiver (GPS Receiver). For this purpose, Explorist 210 GPS receiver was used.

\section{Analysis of sample}

Groundwater samples were examined for chemical parameters, such as total hardness, alkalinity, cadmium, arsenic, nickel, lead, and fluoride. For the determination of hardness, Erichrome Black T (EBT) was used as an indicator in $10 \mathrm{ml}$ of the water sample. The color changed into wine red. $1 \mathrm{ml}$ buffer was added to the hardness solution in the sample using a syringe. It was titrated against the 0.01 $\mathrm{M}$ ethylene diamine tetra acetic (EDTA) solution. The titration was stopped when the color changed to purple. The used volume of EDTA was multiplied by 100 to find the amount of hardness in milligram per liter (Richards 1954). Alkalinity value is found using mathematical formula directly (Shanthivunguturi and Kumar 2014).

Alkalinity $\left(\mathrm{m} \cdot \frac{\mathrm{mole}}{\mathrm{l}}\right)=\left(\right.$ value of $\left.\mathrm{HCO}_{3}\right)(0.02 \mathrm{~N} \mathrm{HCl})$.

The analysis of trace elements, such as cadmium, arsenic, nickel, lead, and fluoride, was performed with the help of

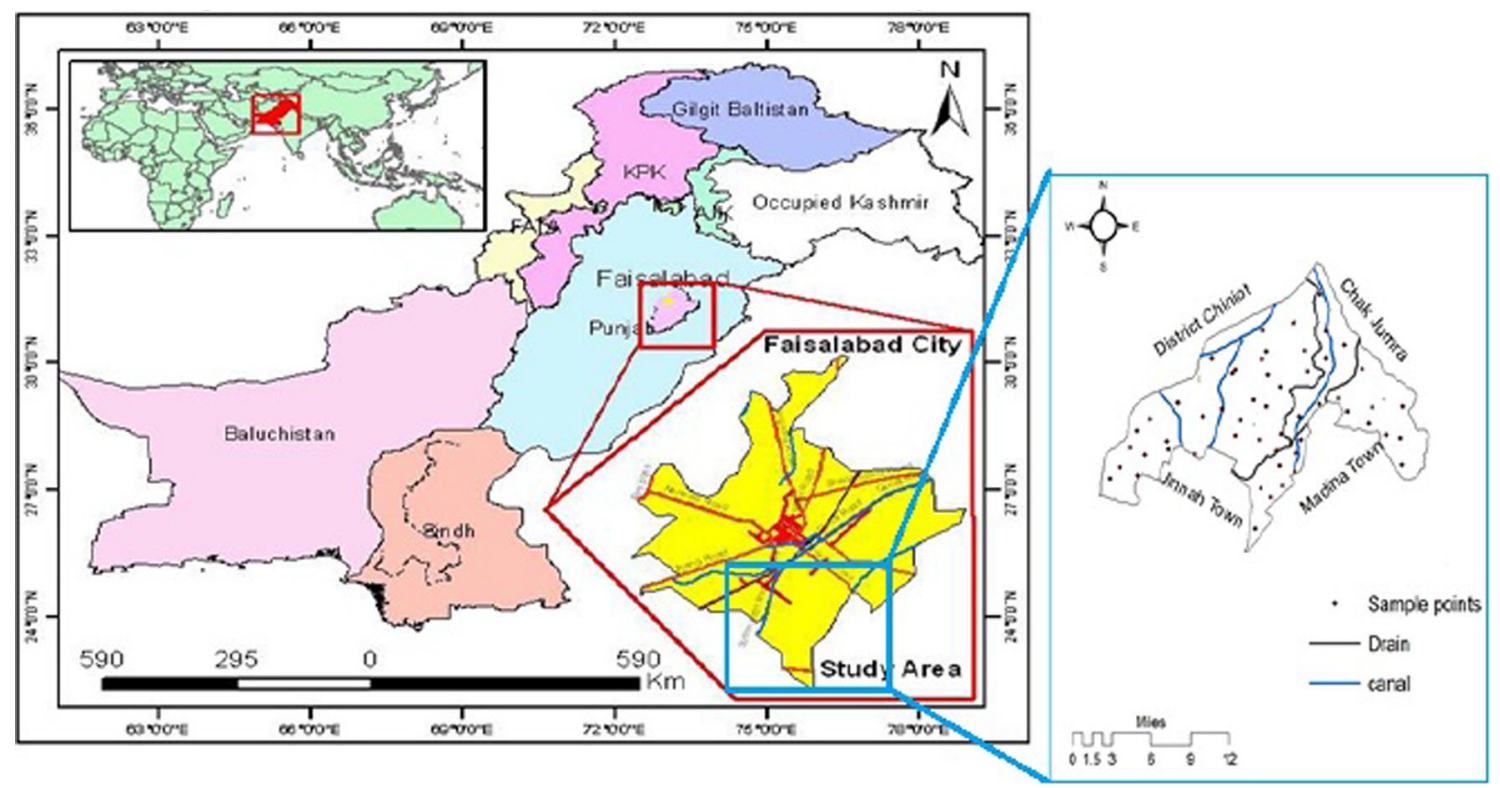

Fig. 1 Study area of industrial zone-Faisalabad 
atomic absorption spectrophotometer. The AAS (AA-6200, Shimadzu) was used for the analysis of these elements. Desired quantity of water sample was taken and 1-2 $\mathrm{ml}$ of conc. HNO3 was added and kept aside for 10-15 min. Whatman filter paper was used to filter the contents. Clear solution was used to note the absorbance in AAS. We took the reading of the filtrate in the AAS. It may directly give the content of the metal depending on the model of AAS, or the concentration of each metal in the sample can be calculated by referring to the standard curve. Quantity of heavy metal in water is calculated in ppm (Niedzielski et al. 2002). The standards techniques were used for the analysis of all the metals and chemical parameters as described in the standard methods. (APHA 1998).

\section{Spatial variability of groundwater quality}

The spatial variability of water quality of an industrial zone was performed using the ArcGIS software v9.3. A topographical sheet covering the study area was scanned and geo referenced with universal transverse (UTM) projection system and world geodetic system (WGS). The location of samples was digitized and database in association with parameters was generated. For the interpolation of data, inverse distance weighting method was used to create a smooth surface.

\section{Long-term analysis of groundwater quality}

To find the future trend of water quality in an industrial zone of Faisalabad, the $\mathrm{R}$ statistical software was used (Hamid et al. 2011). First, we developed a probability distributed curve of the previous year groundwater quality data, then made a mathematical equation that is used for prediction.

\section{Results and discussion}

\section{Hardness analysis}

Hardness in groundwater samples is varied from 97 to $961 \mathrm{mg} / \mathrm{l}$. The permissible limit for hardness is $500 \mathrm{mg} / \mathrm{l}$ (WHO 2011). The GIS analysis of hardness shown in Fig. 2a indicates that the most of the area has hardness value within the permissible limit. Yellow, Green, and Pink colors indicate that the value of hardness is within the limit. The high concentration of hardness is found in the village 197 R.B. Baghian Wala, 130 J.B. Sidhupur, and 55 J.B. Khurdpur that are indicated by purple color on a map. The areas are near to these villages, also having a high hardness value between 530 and $666 \mathrm{mg} / \mathrm{l}$ (Sawyer et al. 2003) and indicated by blue color on a map.
Fig. 2 Spatial variation and future prediction of hardness

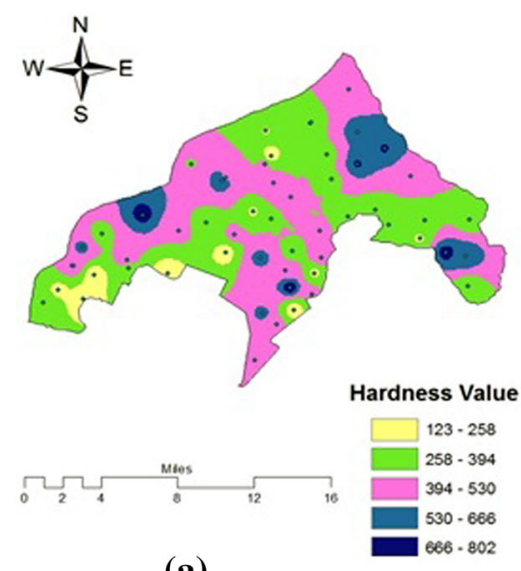

(a)

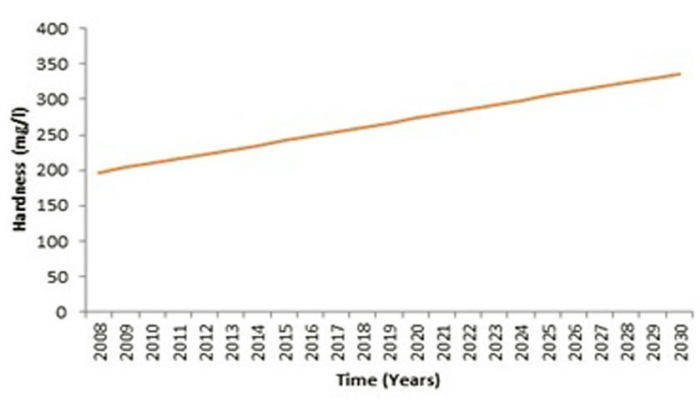

(b)

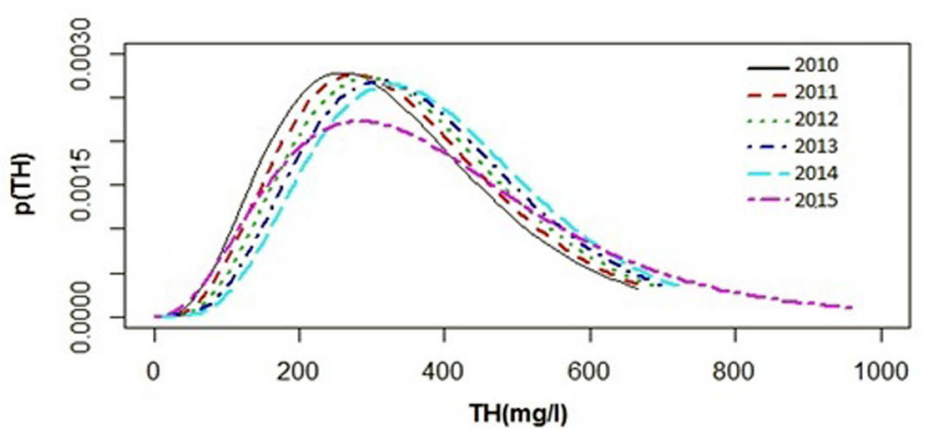

(c) 
The probability density function (pdf) of hardness in different years is shown in Fig. 2c. The peak of each curve represented the mean value of the particular year. From the graph, it is quite clear that the mean value of hardness for the year 2015 is more than 2010. The $R$ square value of the mean of these pdf is 0.7 which indicates that the biasness is $30 \%$. The long-term trend of the hardness of groundwater is shown in Fig. 2b. The straight line tells that there is increasing trend up to 2030 .

\section{Alkalinity analysis}

Alkalinity is the capacity of some of the components of the compound to accept a proton. The principal anions for producing alkalinity of fresh water are sulphate, bicarbonates, and chloride. The alkalinity of groundwater samples of the study area is varied from 1.34 to $13.20 \mathrm{mmol} / \mathrm{l}$. Most of the samples have the alkalinity more than the permissible limit that is $2.77 \mathrm{mmol} / 1$ (CPCB). The GIS analysis of the spatial variability of alkalinity indicates that alkalinity value is more than the permissible limit. Figure $3 \mathrm{a}$ shows the spatial variability in alkalinity. Purple color indicates the highest value of alkalinity in water samples of 55 J.B. Khurdpur $11.2 \mathrm{mmol} / \mathrm{l}$. The green color in the map indicates that the samples in this area have alkalinity value from 3.57 to $5.79 \mathrm{mmol} / \mathrm{l}$.

Figure $3 c$ shows the probability density function of alkalinity in different years. It can be clearly seen that the mean value of alkalinity is increasing every year. The $R$ square value of the mean of these pdf is 0.6 which shows that the biasness is $40 \%$. Figure $3 \mathrm{~b}$ represented long-term trend of alkalinity from 2008 to 2030 on the basis of pdf.

\section{Cadmium analysis}

Cadmium in groundwater samples of industrial zone is varied between 0.001 and $0.012 \mathrm{mg} / \mathrm{l}$. Most of the samples have the cadmium value within the permissible limit that is $0.01 \mathrm{mg} / \mathrm{l}$ (WHO 2011). Figure 4a shows the spatial variability in cadmium. The green color in the map indicates that the samples in this area have cadmium within the permissible limit. The area of high concentration of cadmium is located in Chak \# $105 \mathrm{JB}$ and $110 \mathrm{JB}$ having cadmium value $0.012 \mathrm{mg} / \mathrm{l}$ that is indicated by purple color.

The value of cadmium in an industrial zone is almost negligible in the year 2010-11, as shown in Fig. 4c. There is a significant change during the year 2012-15. The pre-
Fig. 3 Spatial variation and future prediction of alkalinity

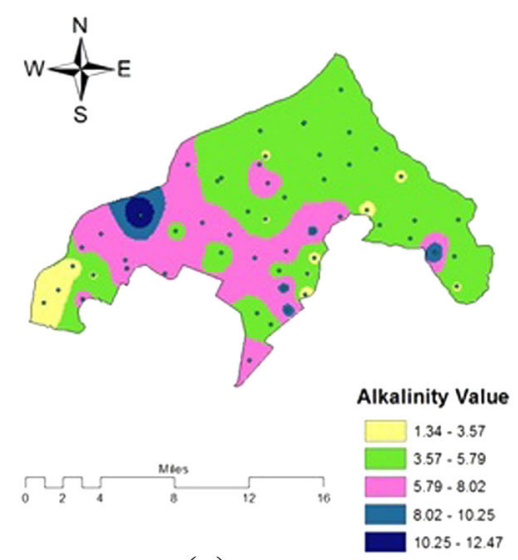

(a)

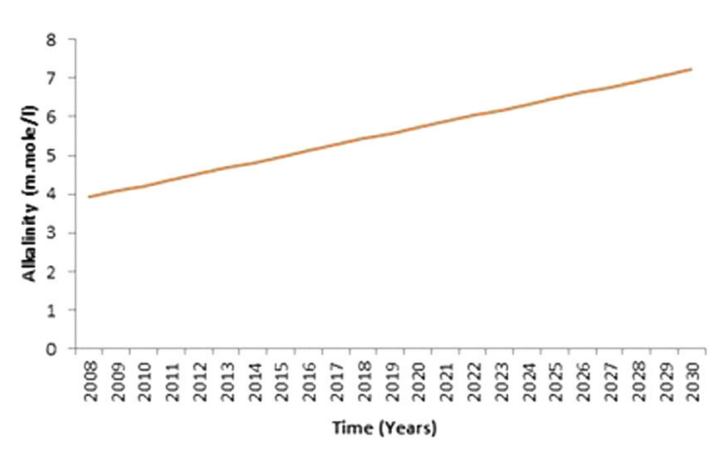

(b)

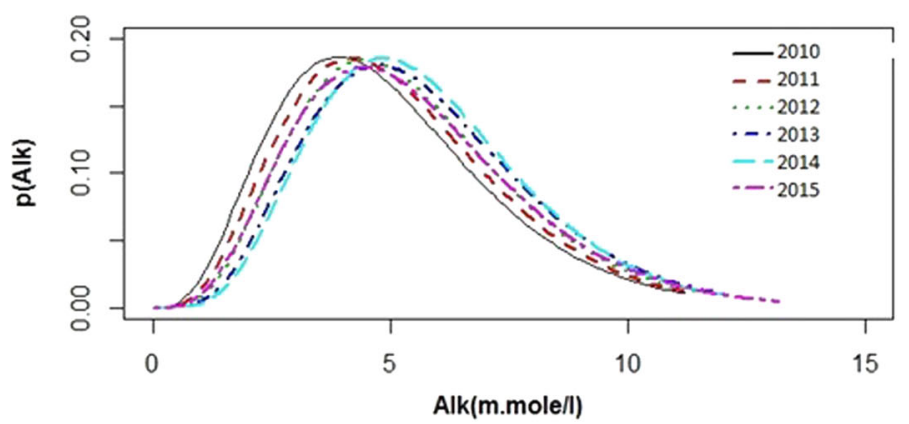

(c) 
Fig. 4 Spatial variation and future prediction of cadmium

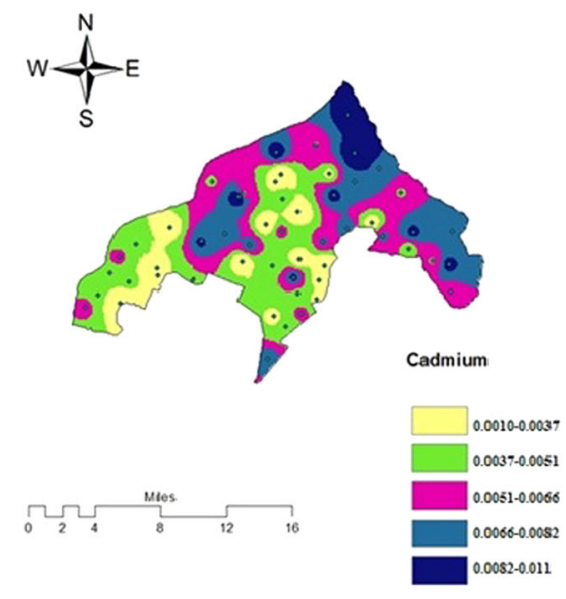

(a)

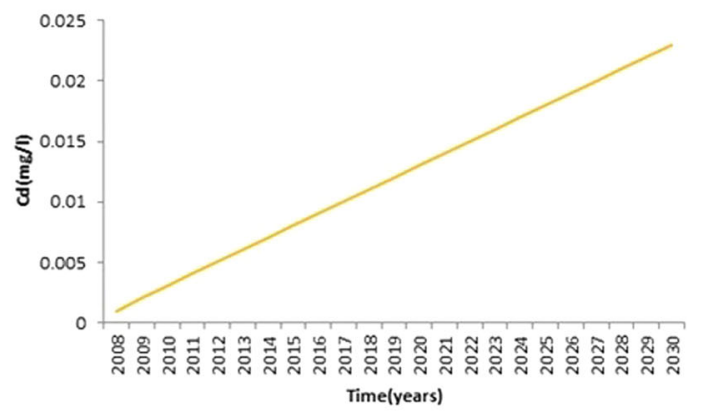

(b)

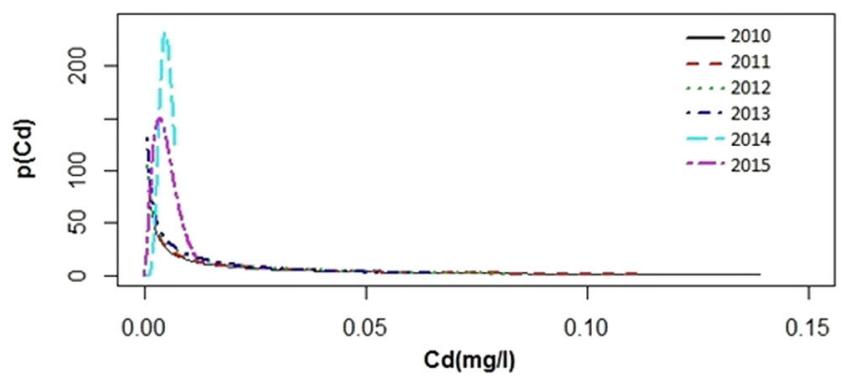

(c)

dicted value for next 20 years can be seen from Fig. $4 \mathrm{~b}$ that there is an increasing trend.

\section{Lead analysis}

The main sources of lead in water are paints, batteries waste, pipes, gasoline, and manufacturing industries. It is a serious body poison. Guideline value for lead is $0.01 \mathrm{mg} / 1$ (WHO 2011). Lead in groundwater samples in the study area is varied between 0.01 and $0.270 \mathrm{mg} / \mathrm{l}$; Fig. 5a indicates the value of lead at different areas. The area having a high concentration of lead is indicated by purple color on a map. The blue color in a map shows that the value of cadmium is more than the guideline value. Most of the industries lie in this area. Industrial drainage is also passed by from this area, so there is more effect.

Figure $5 \mathrm{c}$ shows the probability density function of lead in different years. The peak of each curve is showing the mean value of the particular year. From the graph, it is quite clear that the mean value of a lead for the year 2015 is more than the previous years. The $R$ square value of the mean of these pdfs is 0.9 which shows that the biasness is only $10 \%$. Figure $5 \mathrm{~b}$ represented long-term trend of lead from 2008 to 2030 on the basis of probability distribution function.

\section{Nickel analysis}

Nickel in groundwater samples of study area varied between 0.001 and $0.019 \mathrm{mg} / \mathrm{l}$. It shows that all the samples have the nickel value within the permissible limit that is $0.20 \mathrm{mg} / \mathrm{l}$ (WHO 2011). Figure 6a shows the spatial variability in nickel. The green color in the map indicates that the samples in this area have nickel within the permissible limit. The maximum concentration of nickel in the area is indicated by purple color in a map having nickel value $0.015-0.018 \mathrm{mg} / \mathrm{l}$.

The peak of each curve in Fig. 6c shows the mean value of nickel in the respective year. From the graph, it is quite clear that the value of nickel for the year 2015 is more than 2010. After the statistical analysis, it is clear that there is only $10 \%$ biasness form the original value shown in Fig. $6 \mathrm{~b}$ that is represented long-term trend of nickel from 2008 to 2030 on the basis of probability distribution function.

\section{Arsenic analysis}

Arsenic in groundwater samples varied from 0 to $25 \mathrm{ppb}$. The permissible limit of arsenic by WHO is $10 \mathrm{ppb}$. In most of the samples, arsenic is absent. GIS analysis of the 
Fig. 5 Spatial variation and future prediction of lead

Fig. 6 Spatial variation and future prediction of nickel

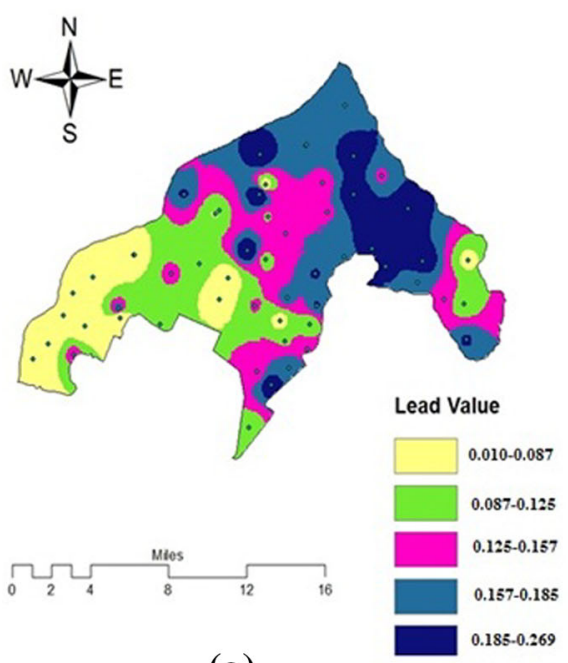

(a)

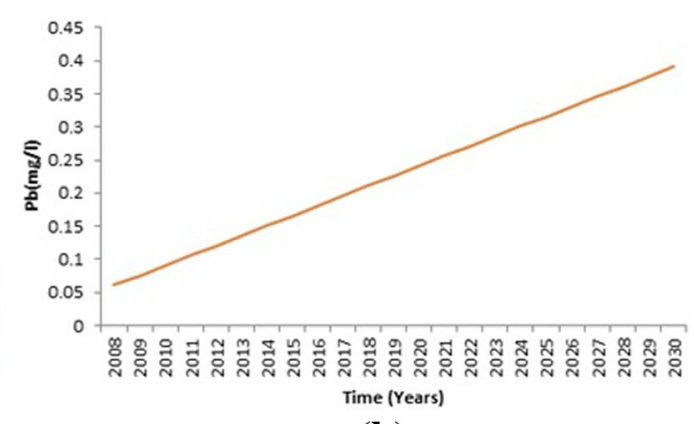

(b)

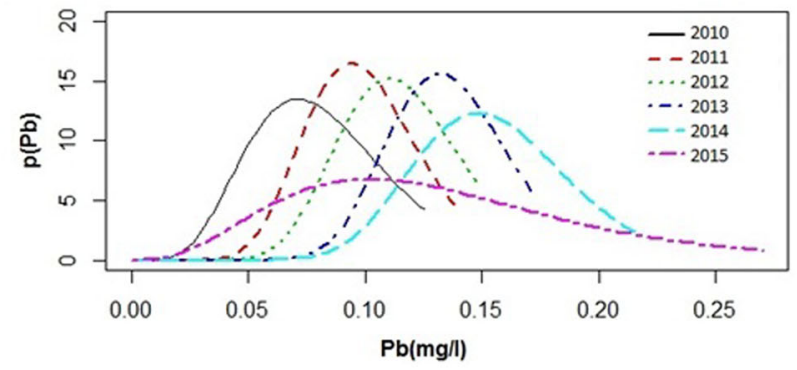

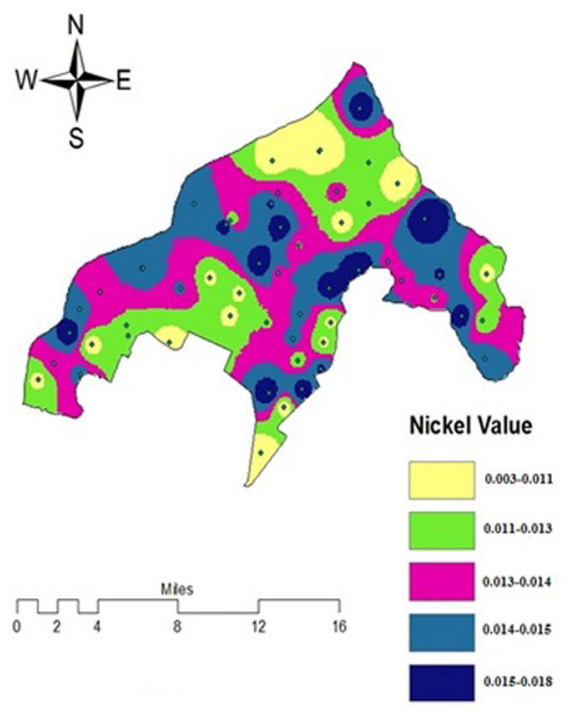

(a)

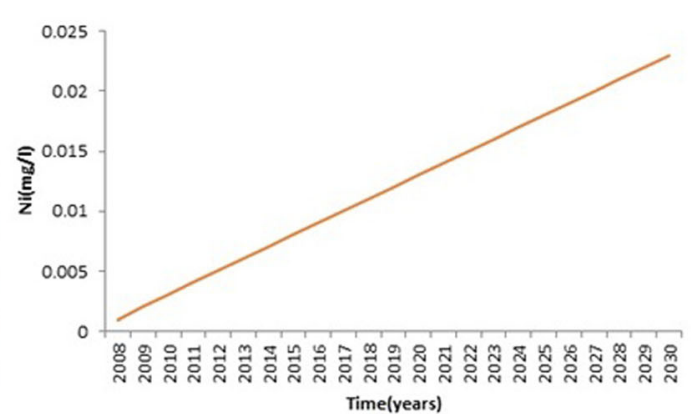

(b)

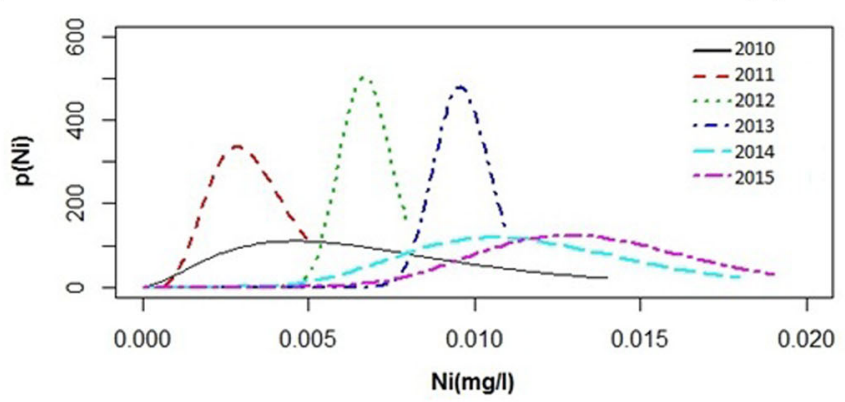

(c) 
Fig. 7 Spatial variation and future prediction of arsenic

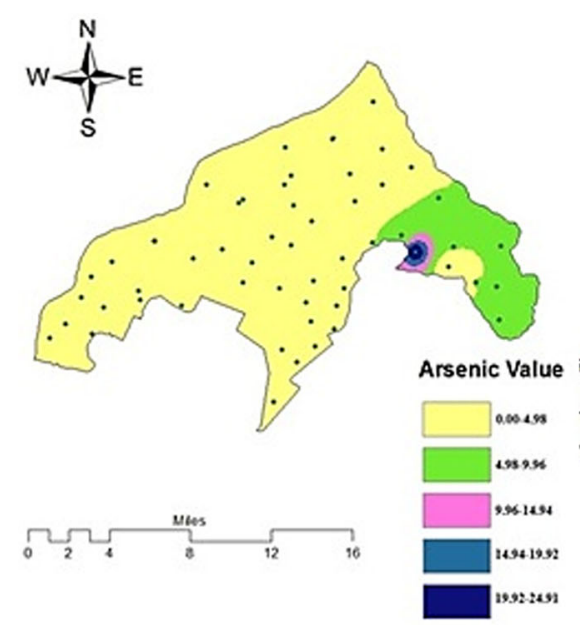

(a)

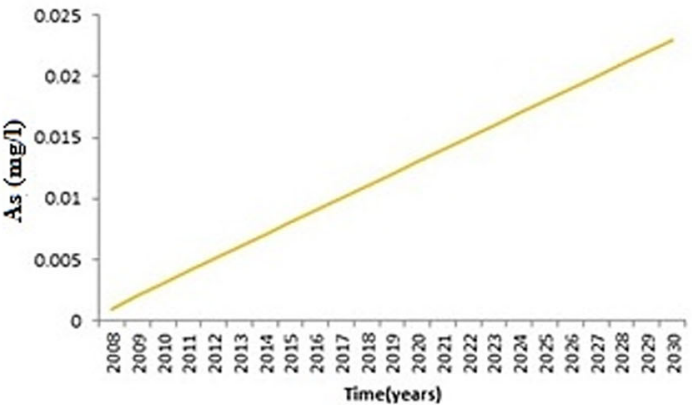

(b)

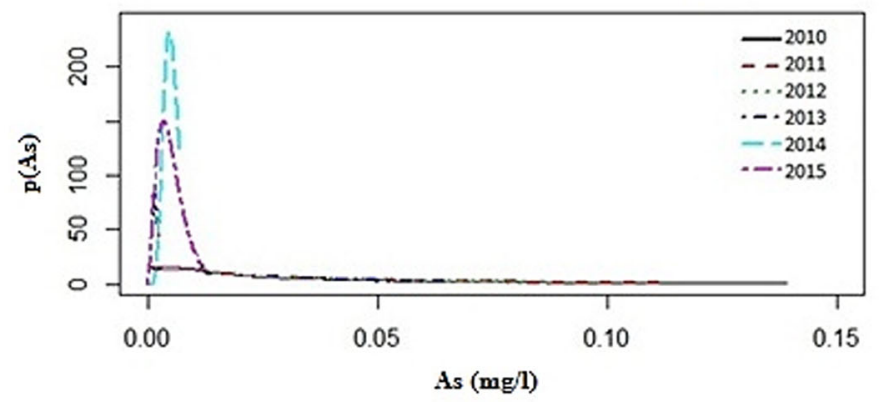

(c)

spatial variability in arsenic indicates groundwater having no arsenic.

Figure 7a shows the spatial variability in arsenic. Yellow color in the map indicates that the samples in this area have no arsenic. The area covering green color indicates that arsenic value is between 4 and $10 \mathrm{ppb}$. The area of high concentration of arsenic is located at Chak \# 196 RB Ghona having arsenic value $25 \mathrm{ppb}$ and indicated by purple color. The area nearer to this point having arsenic value is more than the permissible limit.

Figure $7 \mathrm{c}$ shows the probability density function of arsenic for the year 2010-15. There are only two peak curves for the year 2014-15, because in rest of the year, its value is almost negligible. The number of industries in this zone is increasing, so the arsenic value is becoming more dangerous and it is a serious threat for future, as shown in Fig. $7 b$.

\section{Fluoride analysis}

Drinking water is the main source of fluoride intake. Favorable concentration in water is $1 \mathrm{mg} / \mathrm{l}$; however, greater than $1.5 \mathrm{mg} / \mathrm{l}$ is linked to dental fluorosis and also to cancer. Fluoride in groundwater samples varied from 0 to $2.0 \mathrm{mg} / \mathrm{l}$. Most of the samples have the fluoride value within the permissible limit. The GIS analysis of the spatial variability in fluoride indicates that major area has the groundwater which has fluoride near to permissible limit.

Figure 8a shows the spatial variability in fluoride. Green and pink colors in the map indicate that the samples in this area have fluoride within the permissible limits. The area of high concentration of fluoride is indicated by purple color having fluoride value that is more than the permissible limit.

The long-term trend of fluoride, as shown in Fig. 8b, represents that the concentration of fluoride is increasing gradually and it is very harmful to the human health specially for dental problems, such as mottling of teeth and bending of the spinal cord (Singh et al. 2014).

\section{Conclusion}

The groundwater of industrial zone of Faisalabad is partially not fit for drinking specifically due to the increased concentration of heavy metals. Direct use of this groundwater for drinking purpose may cause health issues, such as cancer, hepatitis, dental, gastrointestinal illness, nausea, eye/nose irritation, etc. The long-term trends of all the groundwater quality parameters revealed that there is an 
Fig. 8 Spatial variation and future prediction of fluoride

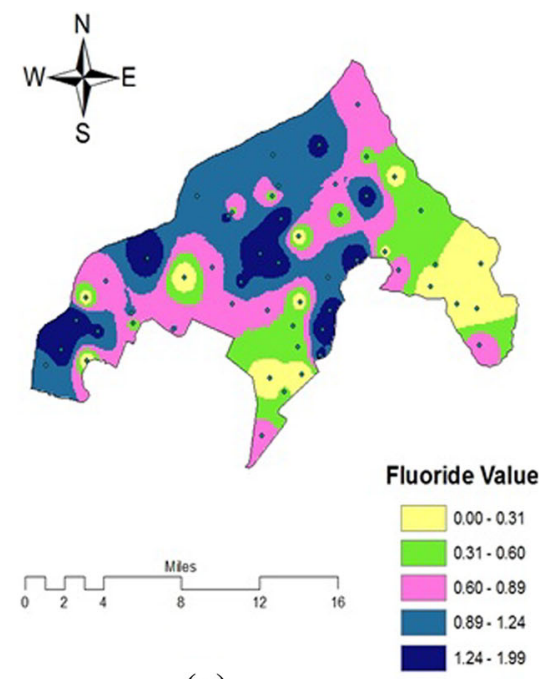

(a)

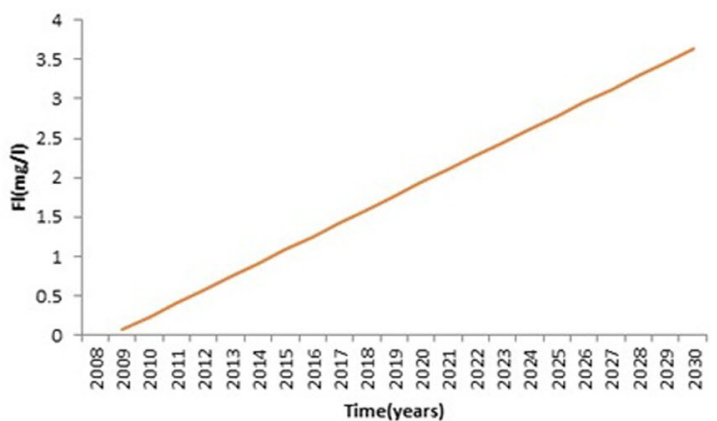

(b)

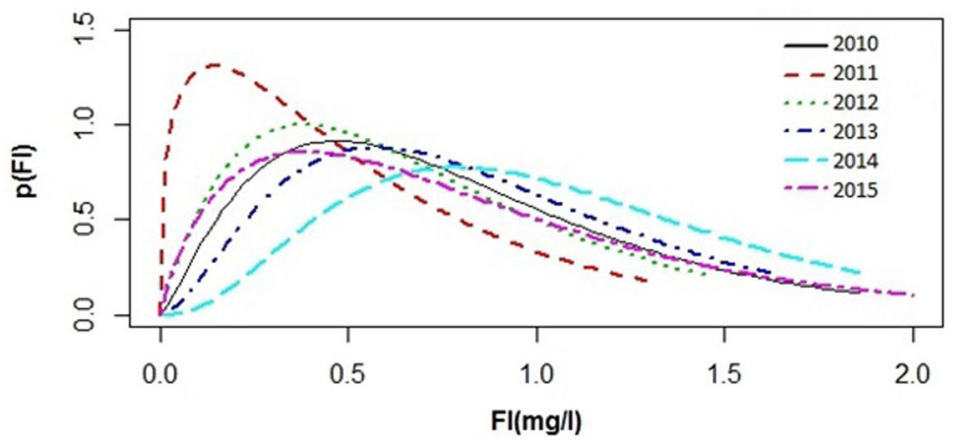

(c)

increasing effect in contamination that appealed for some strategic solution to overcome this trend. The industry is playing a vital role in contaminating groundwater, so further studies should be done to evaluate the role of industry in contaminating groundwater.

Open Access This article is distributed under the terms of the Creative Commons Attribution 4.0 International License (http:// creativecommons.org/licenses/by/4.0/), which permits unrestricted use, distribution, and reproduction in any medium, provided you give appropriate credit to the original author(s) and the source, provide a link to the Creative Commons license, and indicate if changes were made.

\section{References}

Al Hallaq AH, Elaish BSA (2012) Assessment of aquifer vulnerability to contamination in Khanyounis Governorate, Gaza Strip Palestine, using the DRASTIC model within GIS environment. Arab J Geosci 4:833-884

American Public Health association (APHA) (1998) Standard methods for examination of water and wastewater, 20th edn. American Public Health Association/American Water Works Association/Water Environment Federation, Washington
Asma S, Arslan C, Nasir A, Khan A (2012) Physical analysis of groundwater at thickly populated area of Faisalabad by using GIS. Pak J Agri Sci 49:541-547

Bhutta MN, Muhammad R, Chaudhary AH (2002) Ground water quality and availability in Pakistan. In: Proc. seminar on strategies to address the present and future water quality issues, March 6-7, 2002. Pakistan Council of Research in Water Resources, Islamabad, Pakistan. Pub. No. 122, pp 31-36

Dixon B (2005) Groundwater vulnerability mapping: a GIS and fuzzy rule based integrated tool. Appl Geogr 25:327-347

Farah N, Zia MA, Rehman K, Sheikh M (2002) Quality characteristics and treatment of drinking water of Faisalabad City. Int $\mathbf{J}$ Agric Biol 3:347-349

Hamid HS, Vervoort RW, Suweis S, Guswa AJ, Rinaldo A (2011) Stochastic modeling of salt accumulation in the root zone due to capillary flux from brackish groundwater. Water Resour Res 47:WO9506

Kahlown MA, Muhammad A (2003) Water and water quality management in Pakistan. In: Proc. national seminar on strategies to address the present and future water quality issues, March 6-7, 2002. Pakistan Council of Research in Water Resources, Islamabad, Pakistan. Pub. No. 123, pp 37-44

Kouras A, Katsoyiannis I, Voutsa D (2007) Distribution of arsenic in groundwater in the area of Chalkidiki. J Hazard Mater 147:890-899

Nasir A, Muhammad SN, Imran S, Shafiq A, Iqra A (2016) Impact of samundari drain on water resources of Faisalabad City. Adv Environ Biol 10:155-160 
Niedzielski P, Siepak M, Przybyłek J, Siepak J (2002) Atomic absorption spectrometry in determination of arsenic, antimony and selenium in environmental sample. Polish J Envir Stud 11:457-466

Qadir A, Malik RN, Hussain SZ (2008) Spatio-temporal variations in water quality of Nullah Aik-tributary of the river Chenab, Pakistan. Environ Monit Assess 140:43-59

Richards LA (1954) Diagnosis and improvement of saline and alkali soils. USDA Agriculture Handbook 60. Washington

Rizwan U, Riffat NM (2009) Assessment of groundwater contamination in an industrial city, Sialkot, Pakistan. Afr J Environ Sci Tech 3:429-446

Round M (1997) Controversial EPA mercury study endorsed by science panel, environmental news. Environ Sci Technol 31:218-219
Sawyer CN, Mccarty PL, Parkin GF (2003) Chemistry for environmental engineering and science, 5th edn. McGrawHill, New York, p 752

Shanthivunguturi PSR, Kumar YA (2014) Estimation of carbonatebicarbonate alkalinity in water by volumetric and electro analytical methods-a comparative study. Int J Curr Res Chem Pharma Sci 1:151-157

Singh SK, Ghosh AK, Kumar A, Kislay K, Kumar C, Tiwari RR, Parwez R, Kumar N, Imam MD (2014) Groundwater arsenic contamination and associated health risks in Bihar, India. Int $\mathbf{J}$ Environ Res 8:49-60

Uberoi NK (2010) Environmental studies. Second Edition. Excel Printers (Publishers). ISBN 978-81-7446-886-4

WHO (2011) Guidelines for drinking-water quality, 4th edn. World Health Organization, Geneva 